\title{
Environmental warming induces behavioral and metabolic changes in a freshwater crustacean - aeglids as a model organism
}

\author{
Gláucia Bolzan Cogo ${ }^{*}$, Cristiane Biasi, Eduardo Stringini Severo, Vania Loro and Sandro Santos \\ Post-graduate Program in Animal Biodiversity, Ecology and Evolution Department, Center of Natural and Exact Sciences, Federal \\ University of Santa Maria, Brazil. Av. Roraima,1000, 97105-900 Santa Maria, Rio Grande do Sul, Brazil
}

Received: 28 August 2017; Accepted: 8 December 2017

\begin{abstract}
Ecological processes in small-order streams are dependent on their community. A threat to the appropriate functioning of these processes is the water warming of streams since changes in temperature can modify the behavior, abundance, and distribution of the species. A way to predict the consequences of global warming on ecological processes in these ecosystems is to study their aquatic community. Here we evaluated behavioral and metabolic changes in Aegla longirostri at different temperatures $\left(21^{\circ} \mathrm{C}\right.$ and $\left.24^{\circ} \mathrm{C}\right)$. Experiments were performed in laboratory conditions. We calculated leaf consumption and quantified glycogen, protein and amino acid composition in the hepatopancreas. We also conducted a behavioral test to investigate the activity level of aeglids. Leaf consumption did not differ between temperatures. However, the amount of protein was higher at $21^{\circ} \mathrm{C}$, and the amino acid and glycogen levels were greater at $24{ }^{\circ} \mathrm{C}$. In the present study we evaluated only the activity of hepatopancreas, so we can assume that the organ may have used glucose through the breakdown of glycogen and also performing some protein break. However, this hypothesis needs to be confirmed by checking for muscle activity. Animals kept at $24{ }^{\circ} \mathrm{C}$ showed a lower level of activity. This strategy possibly occurs to save energy, as in elevated temperature crustaceans spend extra energy to maintain their homeostasis. This study indicates that a future increase temperature of streams will impact the populations of aeglids by changing their metabolism and behavior.
\end{abstract}

Keywords: Aeglidae / energy reserves / glycogen / protein / shredder

\section{Introduction}

Due to the increase of $\mathrm{CO}_{2}$ in the atmosphere and its contribution to the greenhouse effect, an increase is estimated in the average global air temperature up to $4.8^{\circ} \mathrm{C}$ until 2100 (IPCC, 2014). There is a direct relationship between air temperature and water temperature (Morrill et al., 2005), and an increase of $5^{\circ} \mathrm{C}$ in air temperature can lead to an increase of up to $3.3^{\circ} \mathrm{C}$ in the temperature of water from rivers and streams (Langan et al., 2001; Koycheva and Karney, 2009). Because of the climate changes that have occurred so far, warming of water has already altered the abundance and distribution of some aquatic species such as fish (Perry et al., 2005) and mussels (Galbraith et al., 2010). For the future, it is believed that these global changes in climate have the potential to cause modifications at the individual, population and community levels (Walther et al., 2002). Ecological processes such as carbon mineralization and primary production (Acuña et al.,

\footnotetext{
*Corresponding author: glauciabcogo@gmail.com
}

2008; Demars et al., 2011) also can be affected. These facts point to the importance of understanding how global warming may affect the aquatic communities and the ecosystem processes that occur in these environments (Cole et al., 2007).

In the face of a scenario of climate change, the aquatic communities in small-order streams may be drastically affected, with direct effects on the ecological processes involved (Martínez et al., 2014; Ferreira et al., 2015). The decomposition of allochthonous plant material from riparian vegetation, which is mainly performed by hyphomycetes (Bärlocher, 1992) and invertebrate shredders (Graça, 2001), would be one of these processes with potential deleterious effect on the aquatic community. Changes in water temperature in streams can influence the metabolic rates of these organisms (Brown et al., 2004), thus inducing modifications in their physiology resulting in alterations in their biochemical composition or even suppression of their activities.

The ability of organisms to maintain the stability of an internal environment (homeostasis) is energetically costly. Crustaceans keep the homeostasis through the control of the levels of carbohydrates, lipids and proteins (Dall and Moriarty, 
1983). The relative importance of these reserves and the order of use vary among species, stage of life and type of stress (Jimenez and Kinsey, 2015). Changes in environmental conditions (temperature, $\mathrm{O}_{2}$ availability and salinity) and life cycle changes (reproduction and molting) can modify the amount of these compounds in the body of animals. In crustaceans, the main monosaccharide present in the hemolymph is glucose (Chang and O'Connor, 1983), which is used in the synthesis of chitin and glycogen and pyruvate formation (Jimenez and Kinsey, 2015). When at a high concentration, glucose is stored in the form of glycogen, particularly in the hepatopancreas and muscles (Vinagre and Da Silva, 1992; Oliveira et al., 2003; Buckup et al., 2008). For the most part, lipids are stored in the hepatopancreas (Chang and O'Connor, 1983; Kucharski and Da Silva, 1991) and proteins, in the hepatopancreas and muscles (Claybrook, 1983; Buckup et al., 2008).

A way to predict the consequences of a future scenario of global warming on ecological processes in small-order streams is to study their aquatic community. In the headwater streams of southern Brazil, Aegla longirostri Bond-Buckup and Buckup, 1994 is an important shredder that participates in the process of leaf litter fragmentation (Cogo and Santos, 2013), and it is an essential species in nutrient cycling. These animals live in small-order streams with average annual temperature of $18^{\circ} \mathrm{C}$ (unpublished results). They are often under rocks, and leaf litter and their diet consist mainly of vegetable tissue and insect larvae, being considered omnivores (Santos et al., 2008). Given the above, the objective of this study was to test, under laboratory conditions, if an increase in water temperature will modify leaf consumption, the composition of metabolites in the hepatopancreas and movement of $A$. longirostri. Our hypothesis is that at high temperatures, the metabolism of aeglids will be accelerated, causing (1) an increase in leaf consumption, (2) a decrease in glycogen reserves. Assuming that they will use the breaking of glycogen for energy, (3) there will be no changes in the levels of proteins and amino acids. We also expect that higher temperature will (4) reduce the movement and activity of the animals as a way of saving energy.

\section{Methods}

\subsection{Collection and maintenance of shredders}

We collected specimens of $A$. longirostri manually and with traps in May and June 2015 in a small-order stream, located in the southern region of Brazil (Santa Maria; RS; 29 39'49"S; $\left.53^{\circ} 44^{\prime} 34^{\prime \prime} \mathrm{W}\right)$. The site features a seasonal semideciduous forest with diverse riparian vegetation and an apparent absence of anthropic impact. The stream has areas of pools and riffles, and the substrate is mainly rocky with the presence of leaf litter and sediment deposits (especially in pools). In the experiments, we used only males at the intermolting stage and collected in the same period. This because there are differences between compounds in the hepatopancreas of males and females, aeglids go through a period of fasting during molting, and the reproductive period can change the energy reserves of the animals (Oliveira et al., 2003; Ferreira et al., 2005). After collection, the animals were transported to the laboratory and individually measured for cephalothorax length with a digital caliper (precision: $0.01 \mathrm{~mm}$ ).

Before the experiment, the animals remained (for at least seven days) in individual aquariums $(2 \mathrm{~L})$ with the water temperature of $18^{\circ} \mathrm{C}$, constant aeration, controlled photoperiod (12 h light; $12 \mathrm{~h}$ dark), rock for shelter and ad libitum food (leaf litter collected in the stream). After that, they were randomly separated into two groups and acclimated (three days) in a BOD incubator, in the same conditions (see above) but unfed. The first group was adapted at $21^{\circ} \mathrm{C}$ and the second one at $24^{\circ} \mathrm{C}$. We chose these temperatures because they are above the average water temperature in streams of the region $\left(18^{\circ} \mathrm{C}\right)$ and because at higher temperatures (such as $26^{\circ} \mathrm{C}$ and $27^{\circ} \mathrm{C}$ ) the aeglids have high mortality (preliminary test). At that time, we also conditioned (three days) leaves of Ficus luschnathiana (Miq.) Miq., a plant species used for checking leaf consumption by aeglids. We selected this species because it is abundant in the region and can be found on the banks of debris along the stream. A recent study showed that aeglids consume this species in the natural environment (Cogo and Santos, 2013). The senescent leaves of F. luschnathiana were previously collected, open air dried, wrapped in fine mesh litter bags $(500 \mu)$ and incubated in the stream for 14 days to allow microbial conditioning, a step in which the leaves become more palatable to shredders (Graça et al., 2015).

\subsection{Experiment 1 - fragmentation and biochemical analyses}

In the experiment, the animals were kept alone in aquariums ( $2 \mathrm{~L}$ ) with constant aeration, controlled photoperiod (12 h light; $12 \mathrm{~h}$ dark), rock for shelter. Also, the animals received conditioned leaves discs $(12 \mathrm{~mm})$. Each animal received $370.0 \pm 15.0 \mathrm{mg}$ of dry mass leaf (DM) for consumption. Overall, we used 12 aquaria/animals at $21^{\circ} \mathrm{C}$ and 11 aquaria/animals at $24^{\circ} \mathrm{C}$. Besides, we have kept a control aquarium, where we placed the leaf discs, without the presence of the shredder, to check leaf mass loss as a result of leaching and the action of microorganisms. After two days, the remaining discs (experimental and control) were dried in an oven $\left(60^{\circ} \mathrm{C}\right.$ for two days) and weighed for determination of the remaining DM. Leaf consumption corresponded to the leaf mass loss that occurred in the presence of the shredder, subtracting the value of leaf mass loss obtained in the control aquarium (without shredder).

For the analyses of energy reserve of aeglids, we chose to evaluate glycogen, protein and amino acids in the hepatopancreas, because this is a place of storage of reserves in aeglids (Oliveira et al., 2003; Ferreira et al., 2005). At the end of the experiment, we cryoanesthetized the animals to remove the hepatopancreas, which was stored in a freezer $\left(-20^{\circ} \mathrm{C}\right)$ for subsequent analysis. The level of glycogen in the hepatopancreas was determined by the method described by Bidinotto et al. (1997) after addition of $\mathrm{KOH}$ and ethanol for glycogen precipitation. The tissue was heated with $\mathrm{KOH}$ at $100^{\circ} \mathrm{C}$ and centrifuged at $10000 \mathrm{~g}$ for $10 \mathrm{~min}$ to determine the level of proteins. The supernatant was used to estimate the amount of 
Table 1. Description of the behaviors analyzed and their respective scores.

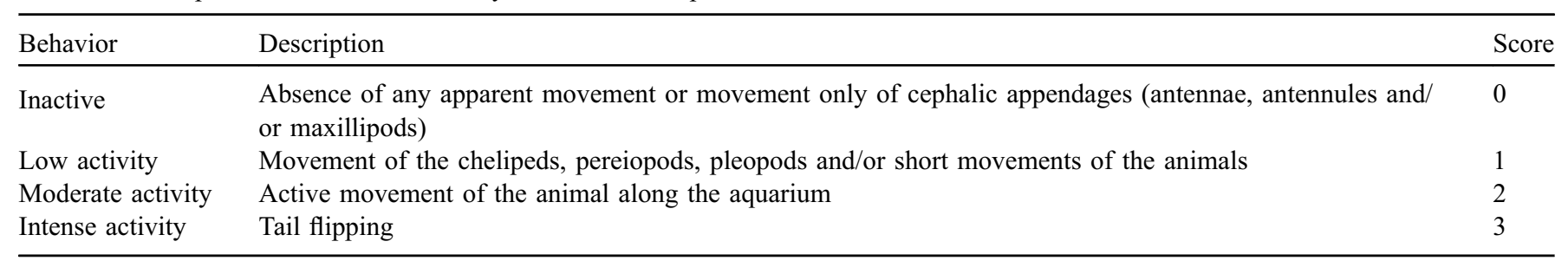

Adapted from Dalosto and Santos (2011).

Table 2. Mean \pm standard error of the variables analyzed in Aegla longirostri at $21^{\circ} \mathrm{C}$ and $24^{\circ} \mathrm{C}$. CL: cephalothorax length. Time with food: time spent manipulating the food; Time without food: time without manipulating food (videotaped over a period of $600 \mathrm{~s}$, only at night).

\begin{tabular}{|c|c|c|c|c|}
\hline & $21^{\circ} \mathrm{C}$ & $24^{\circ} \mathrm{C}$ & The test value & $p$-Value \\
\hline Leaf consumption (mg) & $177.6 \pm 97.7$ & $179.6 \pm 94.3$ & $t=-0.04$ & $P=0.96$ \\
\hline Proteins $\left(\mathrm{mg} \mathrm{g}^{-1}\right)$ & $43.4 \pm 5.2$ & $19.9 \pm 2.5$ & $t=15.19$ & $P<0.0001$ \\
\hline Amino acids $\left(\mu \mathrm{molg}^{-1}\right)$ & $15.1 \pm 1.9$ & $37.8 \pm 2.1$ & $t=-27.20$ & $P<0.0001$ \\
\hline Latency (s) & $28.5 \pm 25.2$ & $136.7 \pm 93.5$ & $U=3$ & $P=0.15$ \\
\hline Time with food (s) & $562.5 \pm 23.5$ & $286.5 \pm 1.9$ & $U=1$ & $P=0.04$ \\
\hline Time without food (s) & $9.0 \pm 9.0$ & $176.7 \pm 74.7$ & $U=1$ & $P=0.04$ \\
\hline
\end{tabular}

proteins following the method described by Lowry et al. (1951). The neutral supernatant was used for colorimetric determination of amino acids according to Spies (1957).

\subsection{Experiment 2 - Behavior}

We made behavioral observations at $10 \mathrm{~h}$ and $22 \mathrm{~h}$ for two days. For $10 \mathrm{~min}(600 \mathrm{~s})$, the animals $\left(N=10\right.$ at $21^{\circ} \mathrm{C}$ and $N=8$ at $24{ }^{\circ} \mathrm{C}$ ) were videotaped (Sony ${ }^{\circledR}$ HDR-CX560 handycam) for later analysis. The activity of aeglids was estimated using specific actions, to which we assigned scores, adapted according to Dalosto and Santos (2011) (Tab. 1). To determine the scores, we divided the $600 \mathrm{~s}$ at 10 -second intervals (totaling 60 ), and during each interval, we annotated the score of the predominant activity (at least $5 \mathrm{~s}$, except for the tail flipping action, which we took into consideration even if the animal persisted for less than $5 \mathrm{~s}$ ). The final score is the sum of the scores given in each interval (they may vary from 0 : inactive animal to 180: maximum activity).

After the observation at $22 \mathrm{~h}$ of the second day, we performed another behavioral observation (videotaped over a period of $600 \mathrm{~s}$, only at night). On this occasion, we offered food to the animals and checked latency, time spent manipulating the food (time with food) and the time without manipulating food (time without food). For this purpose, we chose animals $(N=4)$ at random in each treatment and offered a mix of four pieces of leaves previously collected in the stream. We opted to observe only at $22 \mathrm{~h}$ because aeglids are mostly nocturnal animals (Sokolowicz et al., 2007). We did these observations at night with the use of incandescent redlight bulbs, because crustaceans have low sensitivity to this wavelength (Turra and Denadai, 2003).

\subsection{Statistical analysis}

To test if there was a difference in cephalothorax length, leaf consumption, levels of glycogen, protein and amino acids among treatments, either the t-test or the MannWhitney test was performed, depending on the normality of the data. Differences in behavior between day and night within the same treatment were tested using the Wilcoxon signed-rank test for related samples and differences between treatments were tested with the Mann-Whitney test for independent samples. Mann-Whitney test was used to test differences in latency and time spent manipulating the food. The analyses were performed in the software BioEstat 5.0.

\section{Results}

\subsection{Experiment 1 - fragmentation and biochemical analyses}

The cephalothorax length of the animals and leaf consumption did not differ between the temperatures (Tab. 2). However, the level of protein was higher at $21^{\circ} \mathrm{C}$ while the levels of the amino acids and glycogen were higher at $24^{\circ} \mathrm{C}$ (Tab. 2; Fig. 1). 

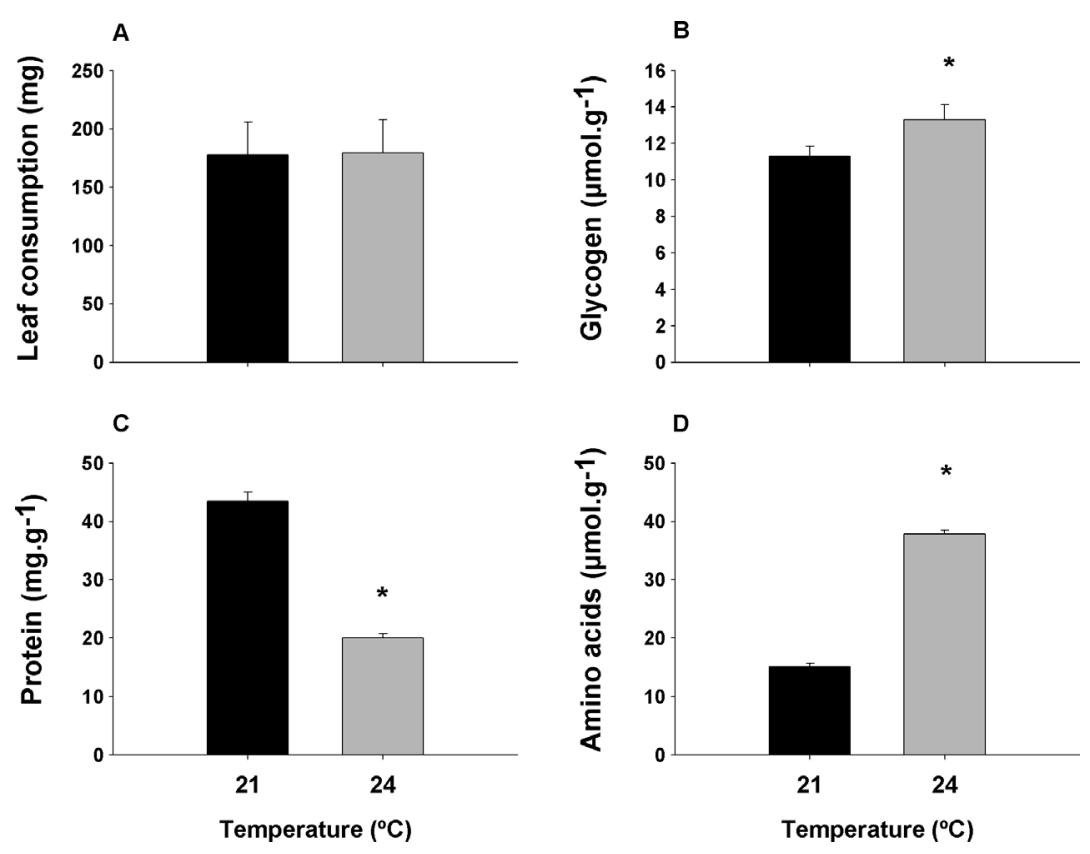

Fig. 1. Consumption and biochemical analyses. Mean \pm standard error of leaf consumption (A), the level of glycogen (B), protein (C) and amino acids (D) in the hepatopancreas of Aegla longirostri at $21^{\circ} \mathrm{C}$ and $24^{\circ} \mathrm{C}$. Asterisks indicate significant differences between the groups.
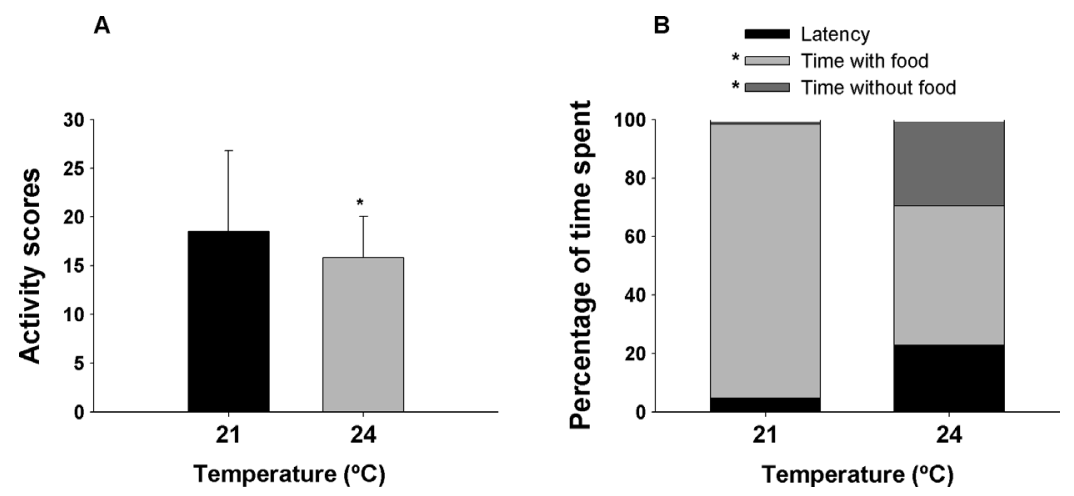

Fig. 2. Behavioral observations. Mean \pm standard error of the average activity scores at $22 \mathrm{~h}(\mathrm{~A})$ and $\%$ of time spent in categories (i) latency, (ii) manipulate the food and (iii) without food in $21^{\circ} \mathrm{C}$ and $24^{\circ} \mathrm{C}(\mathrm{B})$. Asterisks indicate significant differences between the groups.

\subsection{Experiment 2 - Behavior}

There was no difference in the activity of the animals between day and night both at $21^{\circ} \mathrm{C}(Z=1.18, d f=19$; $P=0.24)$, and in $24^{\circ} \mathrm{C}(Z=0.38, d f=15 ; P=0.71)$, as well as between the two days of experiments at different temperatures (Tab. 2). However, during the night $(22 \mathrm{~h})$, the animals at the lowest temperature showed a higher level of activity (Tab. 2; Fig. 2).

Concerning observation of animals after the offer of food, we found that the latency period did not differ between the different temperatures, but the animals at a temperature of $21{ }^{\circ} \mathrm{C}$ spent more time with food than animals at $24^{\circ} \mathrm{C}$ (Tab. 2; Fig. 2B).

\section{Discussion}

Nutrient cycling in small streams that use allochthonous plant material as the main source of energy depends on their aquatic community. Therefore, changes in these organisms due to heating of the water can cause changes in the decomposition of leaf litter and consequently in nutrient cycling. Experiments with higher temperatures have confirmed this hypothesis (Martínez et al., 2014). Increases in water temperature increase the rate of decomposition of leaf litter due to the increase in (i) leaching of soluble compounds (Chergui and Pattee, 1990), (ii) fragmentation and consumption by invertebrates (González and Graça, 2003; Azevedo-Pereira et al., 2006), and (iii) microbial activity (Buzby and Perry, 2000; Canhoto et al., 2016). 
Contrary to these results and our initial prediction, the increase in water temperature did not cause an increase in leaf consumption by $A$. longirostri. At the highest temperature, the aeglids metabolism may not have been speeded up enough to foster an increase in leaf consumption, hence using the energy from food and their energy reserves was sufficient. The absence of differences in leaf consumption at different temperatures may also be related to the chemical quality of the plant species. This characteristic must be considered in a scenario of climate change vs. leaf decomposition because interactions with water temperature can modify the quality of the leaf litter as a function of leaching and mainly of microbial conditioning (Ferreira et al., 2015). The leaves of $F$. luschnathiana were placed in a natural environment, and only after that, they were offered to the aeglids, under experimental conditions. So, the similar results in both experimental conditions tested in this study may be explained by the similar characteristics of the leaves.

Although we have not confirmed our first hypothesis, on leaf consumption, our results show that changes in water temperature produce differences in the biochemical metabolism and the behavior of aeglids. Crustaceans have no particular or specialized organ to regulate their body temperature; hence their metabolic rates vary according to environmental temperature changes (Vernberg, 1982; Lagerspetz and Vainio, 2006) and consequently their energy reserves may be altered. In this study, we observed that the levels of glycogen in the hepatopancreas of aeglids were greater at the highest temperature, and the levels of protein and amino acids differed between the temperatures. Thus, we can say that the aeglids have adopted different strategies for support adverse situation at the analyzed temperatures. At $21^{\circ} \mathrm{C}$, the animals used glucose probably due to glycogen breakdown. On the other hand, at $24^{\circ} \mathrm{C}$, glycogen levels were higher than in aeglids kept at $21^{\circ} \mathrm{C}$, so we suppose that they used some protein hydrolysis. The increase in the level of amino acids at the temperature of $24^{\circ} \mathrm{C}$ suggests that some proteolysis occurred at this temperature. However, the hypothesis needs confirmation through muscle activity measurements. As the supply and concentration of glucose can be derived both from glycogenolysis and gluconeogenesis (Sánchez-Paz et al., 2007), we diagnosed that aeglids used different metabolic pathways. At $21^{\circ} \mathrm{C}$, glucose was produced through the breakdown of glycogen (glycogenolysis), while at $24^{\circ} \mathrm{C}$, amino acids were the source of energy for metabolism. The use of the gluconeogenesis pathway (generation of glucose from breakdown of proteins or amino acids) has already been reported for $A$. platensis fed on some diet rich in protein and low in carbohydrates (Ferreira et al., 2005) and for Neohelice granulata in different diets (Oliveira and Da Silva, 1997).

In different stress conditions, crustaceans use different energy reserves. In this study, at a high temperature, $A$. longirostri decreases its level of proteins, and the same occurs to Carcinus aestuarii, which features lower levels of protein in the hemolymph in this condition (Matozzo et al., 2011). By contrast, Gammarus pulex showed a decrease of its level of glycogen at high temperatures (Foucreau et al., 2014). Glycogen and proteins are typically used during periods of intense activity or changes in environmental conditions for crustaceans (Dutra et al., 2008). The glycogen is used during the process of molting, in periods of fasting, during hypoxia and anoxia, in osmoregulation and growth (Hu, 1958; Chang and O'Connor, 1983; Kucharski and Da Silva, 1991; Oliveira and Da Silva, 2000; Oliveira et al., 2001; Oliveira et al., 2004). In fasting, amphipod crustaceans primarily use the reserves of glycogen and protein and finally the reserves of lipids, while $G$. fossarum uses the reserves of proteins and lipids (Hervant et al., 1999).

Other studies have also found a relation between levels of glycogen and variations in environmental conditions. For example, specimens of Hyalella curvispina have lower levels of glycogen under conditions of increased salinity and lower water volume and temperature (e.g. Dutra et al., 2008). The estuarine crab ( $N$. granulata) also depends on glycogen for their survival during significant variations in environmental parameters such as temperature, salinity and periods of food shortage (Oliveira and Da Silva, 1997). Some studies indicate that seasonal variation in energy reserves of eglids seems to be species-dependent and related to the reproductive period and food availability (Oliveira et al., 2003, 2007). Oliveira et al. (2007) suggested that the physiological characteristics of aeglids are related to their success in exploiting resources available in the environment as well as to the ability to survive in some varied environmental conditions.

The thermal control of crustaceans is based only on behavioral mechanisms, such as stimulus-based changes in locomotion. We know that they avoid extreme temperatures due to the changes in their locomotor activity (e.g. Lozán, 2000) and their movements increase because of thermal preference (Lagerspetz and Vainio, 2006). Aeglids showed less activity at higher temperatures, corroborating our prediction. These animals were dependent on environmental conditions in several studies, such as availability of oxygen (Dalosto and Santos, 2011), availability of particulate organic matter (Bücker et al., 2008) and different land uses, such as urbanization and agriculture (Trevisan et al., 2009). We observed that variations in water temperature influenced the behavior of aeglids, indicating that an increase in global temperature can affect the populations in distinct ways, such as changing the metabolism of animals as well as their behavior (locomotor activity). This strategy may have been used to save energy, because at high temperatures the animals spend extra energy to maintain their homeostasis.

Water temperature is one of the main abiotic factors influencing the survival and growth of decapod crustaceans (Hartnoll, 2001). In the short term, the temperature of $24^{\circ} \mathrm{C}$ caused changes in the metabolism and activity of aeglids but did not affect the survival of these animals. If aeglids become less active at higher temperatures, they may present greater difficulty in finding food, mainly animal material, since they actively search for food resources. However, additional studies in the long term are required to verify the survival of these animals at high temperatures and the possible consequences for their growth and fitness.

The physiological processes of animals comprise a connection between the characteristics of life history and current environmental conditions. Understanding how these processes respond to climate changes can provide evidence about the implications of global warming predicted in biological communities (Small et al., 2015). The present study showed that, as a consequence of global warming, changes might occur in the metabolism and behavior of 
aeglids. Since these crustaceans are strategic consumers of leaf litter and predators in the streams where they live (Cogo et al., 2014; Cerezer et al., 2016), changes in their niche can lead to imbalances in biogeochemical cycles and aquatic trophic chains. However, further long-term studies are necessary for a complete understanding of the consequences of the warming of water resulting from climate change in organisms and ecosystem processes of aquatic environments.

Acknowledgments. This work was supported by Coordenação de Aperfeiçoamento de Pessoal de Nível Superior (CAPES) which offered grants for Gláucia Bolzan Cogo, Cristiane Biasi and Eduardo S. Severo and by Conselho Nacional de Desenvolvimento Científico e Tecnológico (CNPq), which offered grants for Vania Loro and Sandro Santos. We are thankful to Mr. Graciano Sonego, who allowed entry into his property for the collection of plant species and aeglids.

\section{References}

Acuña V, Wolf A, Uehlinger U, Tockner K. 2008. Temperature dependence of stream benthic respiration in an Alpine river network under global warming. Freshw Biol 53: 2076-2088.

Azevedo-Pereira HVS, Graça MAS, González JM. 2006. Life history of Lepidostoma hirtum in an Iberian stream and its role in organic matter processing. Hydrobiologia 55: 183-192.

Bärlocher F. 1992. The ecology of aquatic hyphomycetes. Berlin: Springer-Verlag.

Bidinotto PM, Moraes G, Souza RHS. 1997. Hepatic glycogen and glucose in eight tropical freshwater teleost fish: a procedure for field determinations of micro samples. Bragantia 10: 53-60.

Bond-Buckup G, Buckup L. 1994. A família Aeglidae (Crustacea, Decapoda, Anomura). Arq Zool 32: 159-346.

Brown JH, Gillooly JF, Allen AP, Savage VM, West GB. 2004. Towards a metabolic theory of ecology. Ecology 85: 1771-1789.

Bücker F, Gonçalves R, Bond-Buckup G, Melo AS. 2008. Effects of environmental variables on the distribution of two freshwater crabs (Anomura: Aeglidae). J Crust Biol 28: 248-251.

Buckup L, Dutra BK, Ribarcki FP, Fernandes FA, Noro CK, Oliveira GT, Vinagre AS. 2008. Seasonal variations in the biochemical composition of the crayfish Parastacus defossus (Crustacea, Decapoda) in its natural environment. Comp Biochem Physiol Part A Mol Integr Physiol 149: 59-67.

Buzby KM, Perry SA. 2000. Modeling the potential effects of climate change on leaf pack processing in central Appalachian streams. Can J Fish Aquat Sci 57: 1773-1783.

Canhoto C, Gonçalves AL, Barlocher F. 2016. Biology and ecological functions of aquatic hyphomycetes in a warming climate. Fungal Ecol 19: 201-218.

Cerezer C, Biasi C, Cogo GB, Santos S. 2016. Avoid predation or take risks in basic activities? Predator-prey relationship in subtropical streams between decapods and caddisflies. Mar Freshw Res 67: $1880-1887$.

Chang E, O'Connor JD. 1983. Metabolism and transport of carbohydrates and lipids. In: Mantell LH, ed. The biology of Crustacea: internal anatomy and physiological regulation. New York: Academic Press, pp. 263-287.

Chergui H, Pattee E. 1990. The influence of season on the breakdown of submerged leaves. Arch Hydrobiol 120: 1-12.
Claybrook DL. 1983. Nitrogen metabolism. In: Mantell LH, ed. The biology of Crustacea: internal anatomy and physiological regulation. New York: Academic Press, pp. 163-202.

Cogo GB, Santos S. 2013. The role of aeglids in shredding organic matter in Neotropical streams. J Crust Biol 33: 519-526.

Cogo GB, Biasi C, Santos S. 2014. The effect of the macroconsumer Aegla longirostri (Crustacea, Decapoda) on the invertebrate community in a subtropical stream. Acta Limnol Bras 26: 143-153.

Cole JJ, Prairie YT, Caraco NF, McDowell WH, Tranvik LJ, Striegl RG, Duarte CM, Kortelainen P, Downing JA, Middelburg JJ, Melack J. 2007. Plumbing the global carbon cycle: integrating inland waters into the terrestrial carbon budget. Ecosystems 10: $171-184$

Dall W, Moriarty DJW. 1983. Functional aspects of nutrition and digestion. In: Mantell LH, ed. The biology of Crustacea: internal anatomy and physiological regulation. New York: Academic Press, pp. 215-264.

Dalosto M, Santos S. 2011. Differences in oxygen consumption and diel activity as adaptations related to microhabitat in Neotropical freshwater decapods (Crustacea). Comp Biochem Physiol Part A Mol Integr Physiol 160: 461-466.

Demars BOL, Manso JR, Ólafsson JS, Gíslason GM. 2011. Temperature and the metabolic balance of streams. Freshw Biol 56: $1106-1121$.

Dutra BK, Santos RB, Bueno AAP, Oliveira GT. 2008. Seasonal variations in the biochemical composition and lipoperoxidation of Hyalella curvispina (Crustacea, Amphipoda). Comp Biochem Physiol Part A Mol Integr Physiol 151: 322-328.

Ferreira BDP, Hack CS, Oliveira GT, Bond-Buckup G. 2005. Perfil metabólico de Aegla platensis Schmitt, 1942 (Crustacea, Anomura) submetida a dietas ricas em carboidratos ou proteínas. Rev Bras Zool 22: 161-168.

Ferreira V, Chauvet E, Canhoto C. 2015. Effects of experimental warming, litter species, and presence of macroinvertebrates on litter decomposition and associated decomposers in a temperate mountain stream. Can J Fish Aquat Sci 72: 206-216.

Foucreau N, Cottin D, Piscart C, Hervant F. 2014. Physiological and metabolic responses to rising temperature in Gammarus pulex (Crustacea) populations living under continental or Mediterranean climates. Comp Biochem Physiol Part A Mol Integr Physiol 168: 69-75.

Galbraith HS, Spooner DE, Vaughn CC. 2010. Synergistic effects of regional climate patterns and local water management on freshwater mussel communities. Biol Conserv 143: 1175-1183.

González JM, Graça MAS. 2003. Conversion of leaf litter to secondary production by a shredding caddisfly. Freshw Biol 48: $1578-1592$.

Graça MAS. 2001. The role of invertebrates on leaf litter decomposition in streams - a review. Internat Rev Hydrobiol 86: 383-393.

Graça MAS, Ferreira V, Canhoto C, Encalada AC, Guerrero-Bolaño F, Wantzen KM, Boyero L. 2015. A conceptual model of litter breakdown in low order streams. Internat Rev Hydrobiol 100: 112.

Hartnoll RG. 2001. Growth in Crustacea-twenty years on. Hydrobiologia 449: 111-122.

Hervant F, Garin D, Mathieu J, Freminet A. 1999. Lactate metabolism and glucose turnover in the subterranean crustacean Niphargus virei during post-hypoxic recovery. J Exp Biol 205: 579-592.

Hu ASL. 1958. Glucose metabolism in the crab Hemigrapsus nudus. Arch Biochem Biophys 75: 387-395.

IPCC. 2014. Climate change 2014: synthesis report. In Pachauri RK, Meyer LA, eds. Contribution of Working Groups I, II and III to the 
Fifth Assessment Report of the Intergovernmental Panel on Climate Change. Core Writing Team, IPCC, Geneva, Switzerland, $151 \mathrm{p}$.

Jimenez AG, Kinsey ST. 2015. Energetics and metabolic regulation. In: Chang ES, Thiel M, eds. The Natural History of Crustacean Series: Physiology. Oxford: Oxford University, pp. 389-417.

Koycheva J, Karney B. 2009. Stream water temperature and climate change - An ecological perspective. International Symposium on Water Management and Hydraulic Engineering A112.

Kucharski LCR, Da Silva RSM. 1991. Seasonal variation on the energy metabolism in an estuarine crab, Chasmagnathus granulata (Dana, 1851). Comp Biochem Physiol Part A Mol Integr Physiol 100: 599-602.

Lagerspetz KYH, Vainio LA. 2006. Thermal behaviour of crustaceans. Biol Rev 81: 237-258.

Langan SJ, Johnston L, Donaghy MJ, Youngson AF, Hay DW, Soulsby C. 2001. Variation in river water temperatures in an upland stream over a 30-year period. Sci Total Environ 265: 195-207.

Lowry OH, Rosebrough NJ, Farr AL, Randall RJ. 1951. Protein measurement with the Folin phenol reagent. J Biol Chem 193: 265275.

Lozán JL. 2000. On the threat to the European Crayfish: a contribution with the study of the activity behaviour of four crayfish species (Decapoda: Astacidae). Limnologica 30: 156-161.

Martínez A, Larrañaga A, Pérez J, Descals E, Pozo J. 2014. Temperature affects leaf litter decomposition in low-order forest streams: field and microcosm approaches. FEMS Microbiol Ecol 87: 257-267.

Matozzo V, Gallo C, Marin MG. 2011. Effects of temperature on cellular and biochemical parameters in the crab Carcinus aestuarii (Crustacea, Decapoda). Mar Environ Res 71: 351-356.

Morrill JC, Bales RC, Conklin MH. 2005. Estimating stream temperature from air temperature: implications for future water quality. J Environ Eng 131: 139-146.

Oliveira GT, Da Silva RSM. 1997. Glyconeogeneses in hepatopancreas from Chasmagnathus granulata crabs maintained on highprotein or carbohydrate-rich diets. Comp Biochem Physiol Part A Mol Integr Physiol 118: 1429-1435.

Oliveira GT, Da Silva RSM. 2000. Hepatopancreas gluconeogenesis during hyposmotic stress in crabs Chasmagnathus granulata maintained on high-protein or carbohydrate-rich diets. Comp Biochem Physiol Part B Biochem Mol Biol 127: 375-381.

Oliveira GT, Rossi ICC, Da Silva RSM. 2001. Carbohydrate metabolism during anoxia and pos-anoxia recovery in Chasmagnathus granulata crabs maintained on high-protein or carbohydraterich diets. Mar Biol 139: 335-342.
Oliveira GT, Fernandes FA, Bond-Buckup G, Bueno AA, Da Silva RSM. 2003. Circadian and seasonal variations in the metabolism of carbohydrates in Aegla ligulata (Crustacea:Anomura: Aeglidae). Mem Mus Vic 60: 59-62.

Oliveira GT, Eichler P, Rossi ICC, Da Silva RSM. 2004. Hepatopancreas gluconeogenesis during anoxia and post-anoxia recovery in Chasmagnathus granulata crabs maintained on highprotein or carbohydrate-rich diets. J Exp Zool Part A 301: 240-248.

Oliveira GT, Fernandes FA, Bueno AA, Bond-Buckup G. 2007. Seasonal variations in the intermediate metabolism of Aegla platensis (Crustacea, Aeglidae). Comp Biochem Physiol Part A Mol Integr Physiol 147: 600-606.

Perry AL, Low PJ, Ellis JR, Reynolds JD. 2005. Climate change and distribution shifts in marine fishes. Science 308: 1912-1915.

Sánchez-Paz A, García-Carreño F, Hernández-López J, MuhliaAlmazán A, Yepiz-Plascencia G. 2007. Effect of short-term starvation on hepatopancreas and plasma energy reserves of the Pacific white shrimp (Litopenaeus vannamei). J Exp Mar Biol Ecol 340: 184-193.

Santos S, Ayres-Peres L, Cardoso RCF, Sokolowicz CC. 2008. Natural diet of the freshwater anomuran Aegla longirostri (Crustacea, Anomura, Aeglidae). J Nat Hist 42: 1027-1037.

Small DP, Calosi P, Boothroyd D, Widdicombe S, Spicer JI. 2015. Stage-specific changes in physiological and life-history responses to elevated temperature and $\mathrm{PCO}_{2}$ during the larval development of the European lobster Homarus gammarus (L.). Physiol Biochem Zool 88: 494-507.

Sokolowicz CC, Ayres-Peres L, Santos S. 2007. Atividade nictimeral e tempo de digestão de Aegla longirostri (Crustacea, Decapoda, Anomura). Iheringia Ser Zool 97: 235-238.

Spies JR. 1957. Colorimetric procedures for amino acids. Meth Enzimol 3: 467-477.

Trevisan A, Hepp LU, Santos S. 2009. Abundância e distribuição de Aeglidae (Crustacea:Anomura) em função do uso da terra na bacia hidrográfica do Rio Jacutinga, Rio Grande do Sul, Brazil. Zoologia 26: 419-426.

Turra A, Denadai MR. 2003. Daily activity of four tropical intertidal hermit crabs from southeastern Brazil. Braz J Biol 63: 537-544.

Vernberg FJ. 1982. Respiratory adaptations. In Vernberg FJ, Vernberg WB, eds. The biology of crustacea: environmental adaptations. New York: Academic Press, pp. 1-42.

Vinagre AS, Da Silva RSM. 1992. Effects of starvation on the carbohydrate and lipid metabolism in crabs previously maintained on a high-protein or carbohydrate-rich diet. Comp Biochem Physiol Part A Mol Integr Physiol 102: 579-583.

Walther GR, Post E, Convey P, Menzel A, Parmesan KC, Beebee TJC, Fromentin JM, Hoegh-Guldberg O, Bairlein F. 2002. Ecological responses to recent climate change. Nature 416: 389-395.

Cite this article as: Cogo GB, Biasi C, Severo ES, Loro V, Santos S. 2018. Environmental warming induces behavioral and metabolic changes in a freshwater crustacean - aeglids as a model organism. Ann. Limnol. - Int. J. Lim. 54: 7 